\title{
Lacrimal drainage surgery in Wegener's granulomatosis
}

\author{
Anthony S L Kwan, Geoffrey E Rose
}

\begin{abstract}
Aim-To examine the results of open lacrimal surgery in patients with Wegener's granulomatosis.

Methods-A retrospective review of patients with Wegener's granulomatosis who underwent lacrimal surgery over a 17 year period.

Results-11 patients were identified and a total of 14 primary dacryocystorhinostomies (DCR) and one revisional DCR were performed; symptomatic relief was achieved in 13/14 operations and one patient required revisional surgery for persistent symptoms. There were no intraoperative and few postoperative complications.

Conclusions-In contrast with some previous reports, open DCR appears to be a safe procedure and it is recommended as a treatment for lacrimal obstruction in patients with Wegener's granulomatosis, but an increase of perioperative immunosuppression is recommended in certain cases.

(Br F Ophthalmol 2000;84:329-331)
\end{abstract}

Wegener's granulomatosis is generally a multisystem inflammatory disease of unknown aetiology. Ophthalmic involvement, which includes conjunctivitis, episcleritis, scleritis, corneal ulceration, uveitis, retinal vasculitis, optic neuropathy, and diffuse orbital inflammation, is seen in $29 \%$ of patients and nasolacrimal duct obstruction has been reported in $7 \%$ of patients with this disease. ${ }^{1}$ More limited forms of the disease, often antinuclear cytoplasmic antibody (ANCA) negative, have been recognised in recent years. The presentation, operative outcome and complications for patients with Wegener's granulomatosis who had undergone open dacryocystorhinostomies (DCR) are reviewed and suggestions for the management of this difficult problem are presented.

Moorfields Eye Hospital, London EC1V 2PD

A S L Kwan

G E Rose

Correspondence to:

Mr G E Rose, Lacrimal

Clinic, Moorfields Eye

Hospital, City Road, London EC1V 2PD

Accepted for publication 25 October 1999 tion, duration of disease, preoperative mec therapy, and the results and complications of the surgery were recorded.
A small number of surgeons were involved, all using the following technique. A linear paranasal incision was followed by complete release of medial canthal tendon and a large rhinostomy was created, together with partial anterior ethmoidectomy. Anterior and posterior flaps were formed from both nasal and lacrimal sac mucosa and the anastomoses united with multiple 6/0 Vicryl (Ethicon) sutures. The medial canthal tendon, orbicularis, and skin were closed in layers and silicone stents used in most cases.

\section{Results}

Eleven patients (eight males, three females) are included in the study, aged between 34 to 63 years (mean 52 years) at presentation. Wegener's disease had been present for an average of 9.8 years (range 4-22) and 9/11 patients were maintained on systemic immunosuppression before surgery. Fourteen primary DCRs were performed, with silicone intubation in 11 , and one patient underwent revisional DCR (with intubation) after having had multiple endonasal lacrimal procedures before referral. Extra immunosuppressants were used during the perioperative period in half of the cases. Postoperative complications included membrane formation at the common internal punctum (one case), punctal granuloma (one case), extension of granulomatous disease (one case) and the reformation of a large endonasal cyst previously excised at the time of revisional surgery; this latter patient required further surgery to remove the reformed cyst. Symptoms were cured in $94 \%(14 / 15)$ cases at a mean follow up of 28 months (range 3-96) (Table 1).

\section{Illustrative case reports}

\section{PATIENT 3}

A 56 year old man was referred with bilateral epiphora for 1 year and dacryocystography revealed bilateral mucocoeles. He had Wegener's disease for 4 years that had been controlled for 1 year on a daily maintenance dose of $5 \mathrm{mg}$ prednisolone. Bilateral dacryocystorhinostomies were performed, with silicone intubation being placed because the lacrimal sacs were found to be markedly inflamed with adherent surrounding tissues, evidence of peridacryocystitis. The nasal mucosa was also inflamed and, in view of the operative findings, a course of high dose oral prednisolone (reducing over 3 weeks) was given. He remained asymptomatic at 2 years after surgery. 
Table 1 Patients' characteristics, medications and follow up periods.

\begin{tabular}{|c|c|c|c|c|c|c|c|c|}
\hline $\begin{array}{l}\text { Patient } \\
\text { No }\end{array}$ & $\begin{array}{l}\text { Age at } \\
\text { surgery }\end{array}$ & $\begin{array}{l}\text { Duration of } \\
\text { Wegener's } \\
\text { (years) }\end{array}$ & Preoperative immunosuppression & Operation (side) & $\begin{array}{l}\text { Perioperative } \\
\text { increase in } \\
\text { immunosuppression }\end{array}$ & Complications & $\begin{array}{l}\text { Follow up } \\
\text { (months) }\end{array}$ & $\begin{array}{l}\text { Symptoms } \\
\text { resolved }\end{array}$ \\
\hline 1 & 60 & 5 & Prednisolone $7 \mathrm{mg}$ once daily & $\operatorname{DCR}(\mathrm{L})$ & No & Nil & 6 & Yes \\
\hline 2 & 60 & 22 & $\begin{array}{l}\text { Prednisolone } 15 \mathrm{mg} \text { once daily } \\
\text { Cyclophosphamide } 50 \mathrm{mg} \text { every } \\
3 \text { days }\end{array}$ & $\mathrm{DCR}(\mathrm{R})$ & No & Nil & 60 & Yes \\
\hline 3 & 56 & 4 & $\begin{array}{l}\text { Prednisolone } 5 \mathrm{mg} \text { once daily } \\
\text { Prednisolone } 5 \mathrm{mg} \text { once daily }\end{array}$ & $\begin{array}{l}\text { DCR and tube }(\mathrm{L}) \\
\text { DCR and tube }(\mathrm{R})\end{array}$ & $\begin{array}{l}\text { Yes } \\
\text { Yes }\end{array}$ & $\begin{array}{l}\text { Nil } \\
\text { Nil }\end{array}$ & 24 & $\begin{array}{l}\text { Yes } \\
\text { Yes }\end{array}$ \\
\hline 4 & 55 & 30 & Nil & $\begin{array}{l}\text { DCR and tube (R) } \\
\text { DCR and tube (L) }\end{array}$ & No & $\begin{array}{l}\text { Early failure with } \\
\text { membrane formation } \\
\text { Punctal granuloma } \\
\text { formation at } 1 \text { month }\end{array}$ & 9 & No \\
\hline 5 & 44 & 5 & $\begin{array}{l}\text { Prednisolone } 10 \mathrm{mg} \text { once daily } \\
\text { Azathioprine } 150 \mathrm{mg} \text { once daily } \\
\text { Prednisolone } 7.5 \mathrm{mg} \text { once daily } \\
\text { Cyclophosphamide } 100 \mathrm{mg} \\
\text { once daily }\end{array}$ & $\begin{array}{l}\text { DCR and tube }(\mathrm{L}) \\
\text { DCR and tube }(\mathrm{R})\end{array}$ & $\begin{array}{l}\text { No } \\
\text { Yes }\end{array}$ & $\begin{array}{l}\text { Extension of nasal } \\
\text { granulomatosis to orbit } \\
\text { Nil }\end{array}$ & 48 & $\begin{array}{l}\text { Yes } \\
\text { Yes }\end{array}$ \\
\hline 6 & 49 & 5 & Prednisolone $10 \mathrm{mg}$ once daily & DCR and tube (R) & Yes & Nil & 20 & Yes \\
\hline 7 & 57 & 5 & $\begin{array}{l}\text { Prednisolone } 7.5 \mathrm{mg} \text { once daily } \\
\text { Methotrexate } 15 \mathrm{mg} \text { per week }\end{array}$ & DCR and tube (L) & No & Nil & 6 & Yes \\
\hline 8 & 49 & 10 & $\begin{array}{l}\text { Prednisolone } 7.5 \mathrm{mg} \text { once daily } \\
\text { Azathioprine } 150 \mathrm{mg} \text { once daily } \\
\text { Prednisolone } 7.5 \mathrm{mg} \text { once daily } \\
\text { Azathioprine } 150 \mathrm{mg} \text { once daily }\end{array}$ & $\begin{array}{l}\text { DCR and tube }(\mathrm{R}) \\
\text { DCR and tube }(\mathrm{L})\end{array}$ & $\begin{array}{l}\text { Yes } \\
\text { Yes }\end{array}$ & $\begin{array}{l}\text { Nil } \\
\text { Nil }\end{array}$ & 3 & $\begin{array}{l}\text { Yes } \\
\text { Yes }\end{array}$ \\
\hline 9 & 63 & $\begin{array}{l}9 \text { (recently } \\
\text { confirmed) }\end{array}$ & Nil & $\begin{array}{l}\text { DCR and tube }(\mathrm{L}) \text { and } \\
\text { excision of intranasal } \\
\text { cyst }\end{array}$ & No & $\begin{array}{l}\text { Large reformed } \\
\text { intranasal cyst excised } \\
\text { with canalicular ablation }\end{array}$ & 12 & Yes \\
\hline 10 & 34 & 8 & $\begin{array}{l}\text { Prednisolone } 20 \mathrm{mg} \text { once daily } \\
\text { Azathioprine } 100 \mathrm{mg} \text { once daily }\end{array}$ & $\begin{array}{l}\text { DCR }(\mathrm{L}) \text { and removal } \\
\text { of lid granuloma }\end{array}$ & No & Nil & 96 & Yes \\
\hline 11 & 48 & $\begin{array}{l}5 \text { (recently } \\
\text { confirmed) }\end{array}$ & Prednisolone $20 \mathrm{mg}$ once daily & DCR and tube (L) & Yes & Nil & 3 & Yes \\
\hline
\end{tabular}

PATIENT 4

A 55 year old woman with a 30 year history of Wegener's granulomatosis presented with a 2 year history of bilateral epiphora. The disease had been quiescent for over 10 years on no treatment, although her nasal structure was grossly disorganised (Fig 1).

Dacryocystography showed bilateral small mucocoeles. A right DCR with intubation was performed, together with division of multiple intranasal adhesions, but the symptoms recurred due to gross intranasal scarring over the common canaliculus. Four months later a left DCR with intubation was performed and, at the same time, right canalicular trephination and intubation was performed. No immunosuppressants were given. A pyogenic granuloma was excised from the left inferior punctum at 1 month after surgery and the left side remains symptom free. Right epiphora persisted at 9 months postoperatively, but the patient declined placement of a right canalicular bypass tube.

\section{PATIENT 5}

Left DCR was performed on a 44 year old man who had Wegener's disease for 5 years, controlled on oral prednisolone and azathioprine; biopsy from the lacrimal sac showed that it was clear of disease. One year after the operation, he presented with non-axial left proptosis and computed tomograph scan revealed a presumed intraorbital extension of nasal granulomatous disease through the rhinostomy. ${ }^{2}$ This was successfully treated with high dose prednisolone and cyclophosphamide and, 6 months later, a successful right DCR was performed with prophylactic high dose systemic prednisolone and cyclophosphamide cover. Both sides remained symptom free at 48 months after surgery.
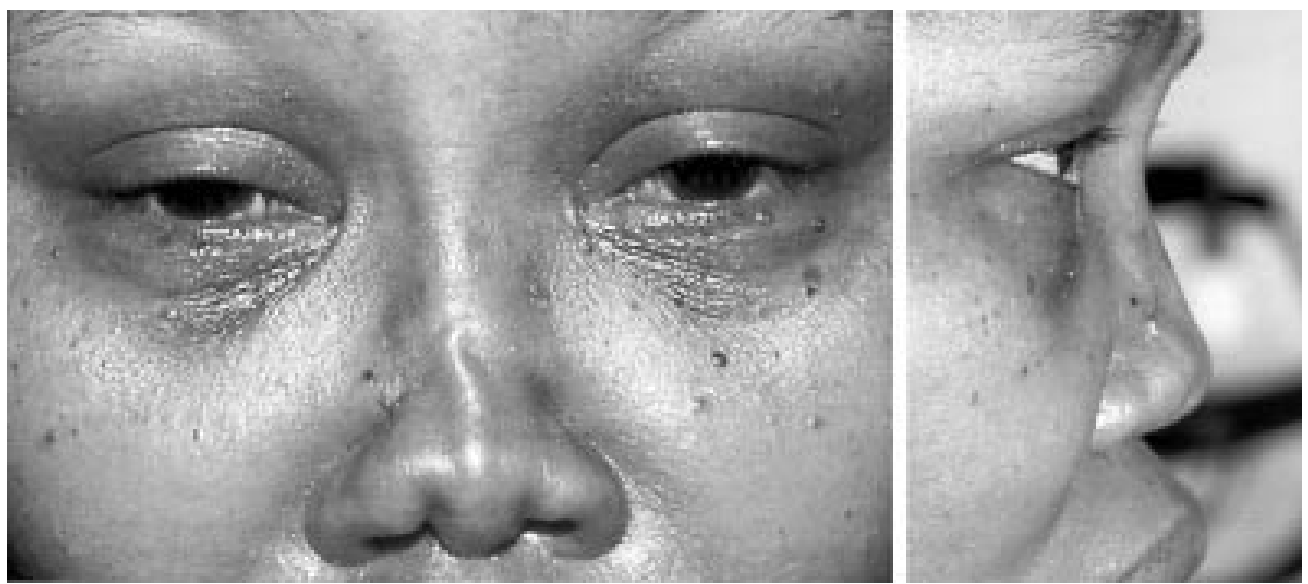

Figure 1 Patient with extensive loss of nasal structure due to long standing Wegener's granuloma (case 4). The collapse of her nasal bridge is associated with loss of the upper portion of the anterior nasal air space, that which normally lies alongside the lacrimal sac fossa. 
PATIENT 9

A 63 year old woman with a 9 year history of epiphora, chronic conjunctivitis, and a severe left toxic keratopathy with stromal vascularisation, who had undergone multiple endonasal DCRs, was referred to our unit. An open revisional DCR with intubation was performed without perioperative systemic steroid. At the time of the operation a large cystic mass was found in the upper half of the nasal space and the septum; this mass being encysted secretions from the frontonasal sinus duct. Excision biopsy of this mass showed features consistent with Wegener's granulomatosis and helped to confirm the clinical diagnosis; serum cANCA was also raised. Owing to reformation of the cyst, her symptoms recurred and revisional dacryocystectomy, with placement of a Jones canalicular bypass tube was planned. During operation the intranasal cyst was found to be draining from the frontal sinus into the canaliculi and the cyst was, therefore, excised and a frontal sinus drainage tube placed. The canalicular system was ablated and there has been a complete resolution of the toxic keratopathy. With good control of her symptoms, the patient has declined placement of a canalicular bypass tube.

\section{Discussion}

Nasolacrimal duct obstruction in Wegener's granulomatosis probably occurs as a direct extension of nasopharyngeal disease and typically is a late manifestation. Postoperative wound necrosis and the formation of nasocutaneous fistula have been reported after DCR in these patients ${ }^{3}$ and dacryocystectomy has been suggested as a treatment for nasolacrimal duct obstruction in this disease. ${ }^{4}$ Others have also reported more encouraging results with DCR. ${ }^{56}$ or have suggested the use of endoscopic DCR in Wegener's disease.

In the present series, all the patients presented in the third to sixth decades, and either had a short (4-5 years) or long (8-30 years) history of symptoms compatible with Wegener's granuloma. Four patients (patients $1,2,7$, and 10) underwent uneventful and successful DCR on their normal maintenance dose of immunosuppressants and three (patients 6,8 , and 11) achieved symptomatic relief with perioperative immunosuppression. $\mathrm{Pa}-$ tient 3 achieved a good result with a short course of high dose prednisolone following discovery of inflamed tissue at the operative site. In patient 4 , the granulomatous disease had been quiescent for over 10 years, but the extensive scarring in the nose was associated with dense membrane formation over the rhinostomy and failure; surgery on the contralateral side, without adjuvant systemic immunosuppression, was curative. Despite prednisolone and azathioprine cover, there was an intraorbital progression of the nasal granuloma through the rhinostomy in one patient (patient 5), this orbital disease settling with increased immunosuppression and later surgery to the other eye was uncomplicated after giving prophylactic high dose systemic steroids. ${ }^{2}$ Wegener's disease was not recognised in patient 9 and multiple previous attempts of endoscopic laser DCR (before referral) were without immunosuppression and associated with extensive nasal scarring and formation of a massive intranasal cyst-these changes undoubtedly compromising the definitive lacrimal surgery. Endoscopic DCR may be inappropriate in the presence of major nasal inflammatory disease, as illustrated in this case, and we consider that the large rhinostomy achievable with external surgery may help in the long term success of the operation. There have been similar recommendations for patients with sarcoidosis who are undergoing lacrimal surgery. ${ }^{8}$ In contrast with a previous report, ${ }^{3}$ wound necrosis and nasocutaneous fistula were not seen in our series and there was only one early failure because of canalicular occlusion developing in an extensively scarred nasal space.

We recommend open DCR as a safe and effective treatment for nasolacrimal obstruction in patients with controlled Wegener's granulomatosis. An increase in systemic immunosuppression should be considered for a few weeks after surgery in unstable disease, or when active disease is seen during surgery, and the patient monitored closely for recurrent or spreading postoperative disease.

1 Bullen CL, Liesegang TJ, McDonald TJ, et al. Ocular complications of Wegener's granulomatosis. Ophthalmology 983;90:279-90.

2 Kwan ASL, Rose GE. Orbital Wegener's granuloma resulting from direct extension of nasal disease through a surgical rhinostomy. Br f Ophthalmol 1998;82:198.

3 Jordan DR, Miller D, Anderson RL. Wound necrosis following dacryocystorhinostomy in patients with Wegener's granulomatosis. Ophthalmic Surg 1987;18:800-3.

4 Holds JB, Anderson RL, Wolin MJ. Dacryocystectomy for the treatment of dacryocystitis in patients with Wegener's granulomatosis. Ophthalmic Surg 1989;20:443-4.

5 Glatt HJ, Putterman AM. Dacryocystorhinostomy in Wegener's granulomatosis. Ophthalmic Plast Reconstr Surg 1990; 6:207-10

6 Hargwig PW, Bartley GB, Garrity JA. Surgical management of nasolacrimal duct obstruction in patients with Wegener's granulomatosis. Ophthalmology 1992;99:133-9.

7 Wong RJ, Gliklich RE, Rubin PA, et al. Bilateral nasolacrimal duct obstruction managed with endoscopic techniques. Arch Otolaryngol Head Neck Surg 1998;124: 703-6.

8 Chapman KL, Bartley GB, Garrity JA, et al. Lacrimal bypass surgery in patients with sarcoidosis. Am f Ophthalmol 1999;127:443-6. 